\title{
Cold Plasma: An Alternative in Litopenaeus vannamei Shrimp Preservation
}

\begin{abstract}
Lucas de Oliveira Soares Rebouças, Julianna Paula do Vale Figueiredo, Maria Carla da Silva Campelo, Jovilma Maria Soares de Medeiros, Renata Bezerra Gomes Rebouças, Clodomiro Alves-Junior, Jean Berg Alves da Silva, Patrícia de Oliveira Lima
\end{abstract}

UFERSA, Brazil

Received: February 23, 2021

doi:10.5296/jas.v9i2.18341
Accepted: April 10, $2021 \quad$ Published: May 27, 2021

URL: https://doi.org/10.5296/jas.v9i2.18341

\begin{abstract}
This study aimed evaluating the effects of cold plasma on the quality attributes of Pacific white shrimp (Litopenaeus vannamei). Shrimp were divided into 4 sample groups: one control and the remaining groups subjected to cold plasma at frequencies of 5, 10, and 15 $\mathrm{kHz}$, respectively, during 10 minutes of application followed by evaluation of chemical, physical, microbiological, and sensorial characteristics. Cold plasma contributed significantly to the maintenance of shrimp quality during storage, delaying the melanization process, microbial growth, improving the physicochemical and sensorial qualities of the samples. Exposure of white shrimp to non-thermal plasma at $15 \mathrm{kHz}$ promoted better physicochemical, microbiological, and sensorial results, and increased the shelf life of samples by 5 days, suggesting that the treatment is effective to preserve the quality of shrimp.
\end{abstract}

Keywords: seafood, deterioration, melanosis, cold plasma

\section{Introduction}

Shrimp is highly appreciated because of its sensory and nutritional characteristics; however, due to some aspects of its composition such as high moisture content (between $70 \%$ and $85 \%$ ), it is highly perishable with a short shelf life (Tsironi et al. 2009). This factor, coupled with poor storage and commercialization conditions, results in rapid deterioration and a consequent decrease in market value (Yuan et al., 2016).

Black spot, or melanose formation is among the most important processes in the deterioration of crustaceans that cause great problems for the industry. It involves progressive blackening of articulations and exoskeleton of these animals, particularly in the cephalothorax region by enzymatic oxidation of phenolic compounds. Although it is harmless to consumers and is not directly associated with microbial deterioration, melanosis affects sensory characteristics and reduces shelf life and product quality (Gonçalves \& Oliveira, 2016). 


\section{Macrothink

Due to this problem, the fish industry is increasingly seeking clean technologies to improve technologies shrimp processing, aiming for competitive advantages and social concerns regarding environmental impacts (Basseto, et al. 2017). Cold plasma is one of the clean technologies gaining space in the food industry. Cold plasma is defined as a partially ionized gas containing molecules and charged particles in the form of positive ions, negative ions, free radicals, electrons, UV, and photons (Misra et al. 2011).

Atmospheric cold plasma produced by dielectric barrier discharge in air produces several important species that can be used to inactivate a wide range of microorganisms, including spores and viruses (Misra et al., 2011). Reactive oxygen species (ROS) and reactive nitrogen species (RNS) in concert with UV radiation, which has already demonstrated antimicrobial efficacy may also be beneficial in the fish industry to prolong the shelf life of fresh products and maintain safety throughout the food chain (Smeu, \& Ioananicolau, 2014; Gonçalves, 2015).

Thus, the objective of this study was to evaluate the use of cold atmospheric plasma as an alternative to guarantee the microbiological safety, physicochemical properties, and sensorial quality of fresh white shrimp (Litopenaeus vannamei) during storage nitrogen $78 \%$, oxygen $21 \%$ and argon $0.9 \%$ ).

\section{Material and Methods}

\subsection{Raw Material and Sampling}

Approximately $20 \mathrm{~kg}$ of fresh white shrimp (L. vannamei) with an average body weight of 10 grams and free of additives, was purchased from a farm located in State of Rio Grande do Norte. Shrimp were weighed and separated into four sample groups: the control group and three groups in which the items were exposed to treatment with cold plasma at $5 \mathrm{kHz}, 10 \mathrm{kHz}$ and $15 \mathrm{kHz}$, respectively, with a contact time of 10 minutes, since the maximum frequency of the equipment used was $15 \mathrm{kHz}$.

\subsection{Plasma Generation}

The cold plasma generator system was run with an dielectric barrier type (DBD) configuration using coplanar phenolitic plates, which provide electric discharges, with atmospheric air as the working gas, thus generating reactive oxygen species (ROS), ultraviolet (UV) radiation, and a high electric field (Figure 1). 


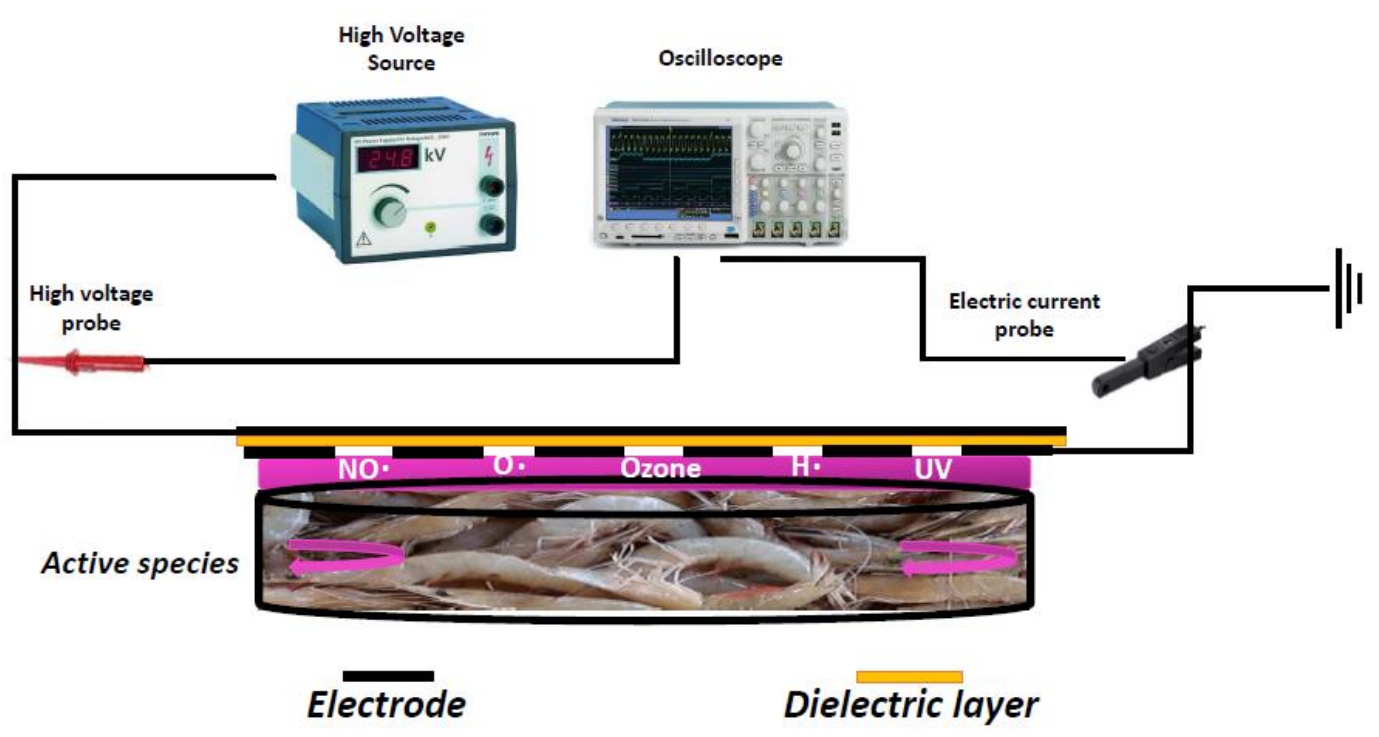

Figure 1. Experimental system for cold plasma generation using atmospheric gas as ionizing gas

Samples were placed in a Petri dish of $80 \mathrm{~mm}$ in diameter and $15 \mathrm{~mm}$ depth. During treatment, the plasma remained at a distance of approximately $3 \mathrm{~mm}$ from the samples (with no effective contact between the plasma and treated shrimp, and no localized discharges were formed). Thus, as they were submitted to the following experimental conditions: 10 minutes and after 5 minutes they were turned over, so that all people could receive the same treatment. The equivalent frequency energy parameters: $5 \mathrm{kHz}, 10 \mathrm{kHz}, 15 \mathrm{kHz}$, respectively, and $40 \mathrm{kV}$ electrical voltage. After treatment, the sample groups were packed in sterile plastic containers and stored at $5 \pm 1^{\circ} \mathrm{C}$.

\subsection{Quality Analysis}

The following attributes were determined to evaluate the physicochemical quality of the samples: $\mathrm{pH}$, color variation during storage $\left(\Delta \mathrm{e}=\left[\left(\mathrm{L}^{*}-\mathrm{L}^{*} 0\right)^{2}+\left(\mathrm{a}^{*}-\mathrm{a}^{*} 0\right)^{2}+\left(\mathrm{b}^{*}-\mathrm{b}^{*} 0\right)^{2}\right]^{1 / 2}\right.$, $)$ using the coordinates $\mathrm{L}^{*}, \mathrm{a}^{*}$, and $\mathrm{b}^{*}$ (Yuan et al., 2016), water holding capacity (Hamm, 1961; Barbetta \& Grigio, 2014), weight loss by cooking (Warris, 2003), shear force (Hamm, 1961), nitrogen content of the total volatile bases (N-TVB), and trimethylamine nitrogen (N-TMA) according to the protocol of LANARA (Brasil, 1981), 2-Thiobarbituric acid reactive substances (TBARS) using the method described by Tarladgis, Watts \& Younathan (1960).

\subsection{1 $\mathrm{pH}$}

The measurement of the hydrogen potential was performed by an electrometric process with the digital $\mathrm{pH}$ meter of the HANNA® model HI 99163, previously calibrated. The measurement was made in the peeled shrimp, as the equipment has a specific probe, with a conical tip in a stainless steel blade, which helps its insertion into the muscle.

\subsubsection{Color}

For color determination, the Konica Minolta Portable Spectrophotometer, CM-700d / 600d 
(CIE System $L^{*} a^{*} b^{*}$ ) was used, whose system considers the coordinates $L^{*}$ luminosity (black / white), a* red content (green / red) and b* yellow (blue / yellow) content (Yuan et al., 2016). The total variation of the color coordinates ( $\Delta$ e values), which is the amplitude of the differences in the color coordinates of the shrimp at the beginning and during storage, were calculated following the equation described by Yuan et al. (2016), $\Delta \mathrm{e}=\left[\left(\mathrm{L}^{*}-\mathrm{L}^{*} 0\right)^{2}+\left(\mathrm{a}^{*}-\right.\right.$ $\left.\left.a^{*} 0\right)^{2}+\left(b^{*}-b^{*} 0\right)^{2}\right]^{1 / 2}$.

\subsubsection{Weight Losses During Cooking (WL)}

Weight losses during cooking (WL) were calculated by the difference in weight of the samples, before and after cooking, and expressed as a percentage. The treated samples were wrapped in aluminum foil and with the aid of a thermometer, they were grilled until they reached a temperature of $70^{\circ} \mathrm{C}$ (Warris, 2003).

\subsubsection{Shear Force}

The shear force was measured using a TEXTURE ANALYZER TAXT-125, coupled to the Warner-Bratzler device, which expresses the force in $\mathrm{kgf} / \mathrm{cm}^{2}$ (Hamm, 1961).

\subsubsection{N-BVT and TMA}

For the analysis of N-BVT and TMA, $50 \mathrm{~g}$ of muscle from each treatment were weighed on an analytical balance and, after adding $150 \mathrm{~mL}$ of $10 \%$ trichloroacetic acid, they were crushed inside beakers with the aid of pistils. After being homogenized, the mixture was filtered (quantitative filter paper $110 \mathrm{~mm}$ ) in flat bottom volumetric flasks to obtain a clear extract. From this extract, $5 \mathrm{~mL}$ were removed and transferred to a digester tube, coupled to the Tecnal ${ }^{\circledR}$ Model TE-0363 nitrogen distillation device, which contained $5 \mathrm{~mL}$ of $2 \mathrm{M}$ sodium hydroxide $(\mathrm{NaOH})$ to start the distillation. In the distillation process, the distillate was collected in an Erlenmeyer flask containing $5 \mathrm{ml}$ of $0.01 \mathrm{~N}$ hydrochloric acid and three drops of the rosolic acid indicator, until the volume of $50 \mathrm{ml}$ of a clear, fully transparent solution was reached. Then, the clear distillate was subjected to titration of the excess acid with $0.01 \mathrm{~N}$ $\mathrm{NaOH}$ until it reached a pale pink color. This first titration refers to the value of N-BVT. To calculate the TMA, $5 \mathrm{~mL}$ of $16 \%$ formaldehyde were added to the resulting N-BVT solution, so that the solution would become transparent again and a second titration with $0.01 \mathrm{~N} \mathrm{NaOH}$ was carried out until the liquid turned pink again. TBARS was determined using the method described by Tarladgis et al. (1960), to assess the triggering of the lipid oxidation process after treatment with cold plasma. The reaction was measured on a spectrophotometer at $538 \mathrm{~nm}$ wavelengths. The samples were analyzed in triplicate. The results of the TBARS index were expressed in $\mathrm{mg} / \mathrm{kg}$.

\subsubsection{Microbiologial Analysis}

The microbiological analyzes of the samples were performed in duplicate at times $0,1,3,6,9$ and 12 days of refrigerated storage at $5^{\circ} \mathrm{C} \pm 1^{\circ}$. For these analyzes, the samples were subjected to the techniques for determining the total count of mesophilic and psychrotrophic bacteria and Salmonella sp. (Brasil, 2003). 


\subsubsection{Quality Index Method (QIM)}

The Quality Index Method (QIM) is a fish freshness quality control system aimed to evaluate the main sensorial attributes of the evaluated species through a system of demerit points. Although an important tool, QIM should be estimated with the support of other assessment methods such as microbiological and physicochemical analyses (Martindóttir et al., 2003).

The Quality Index (QI) was determined using the scheme proposed by Gonçalves, Oliveira \& Abrantes (2015), where five evaluators were previously trained to evaluate shrimp samples according to ISO 8586 standards (ISO 8586, 1993, pp. 1-10). The quality parameters observed in the samples were included aroma, presence of melanose, texture, adherence of the head, adhesion of the carapace, and general appearance. The QI represents the sum of all the demerit points of a given sample, ranging from 0 to 36 (Table 1).

Table 1. QI method scheme used in this research

\begin{tabular}{|c|c|c|}
\hline $\begin{array}{l}\text { Quality } \\
\text { paramet } \\
\text { er }\end{array}$ & $\begin{array}{c}\text { Descriptio } \\
n\end{array}$ & Score \\
\hline \multirow{4}{*}{ Aroma } & Fresh, smooth as seaweed & [0] \\
\hline & Faint, reminiscent of sea salt & {$[2]$} \\
\hline & Light ammonia scent & [4] \\
\hline & Heavy ammonia scent, putrid & [6] \\
\hline \multirow{6}{*}{ Melanosis } & Absent & [0] \\
\hline & $\begin{array}{l}\text { Slight, small isolated black spots, occurring in up to } 50 \% \text { of } \\
\text { shrimp samples }\end{array}$ & {$[2]$} \\
\hline & $\begin{array}{l}\text { Moderate, small isolated black spots, occurring in over } 50 \% \text { of } \\
\text { shrimp samples }\end{array}$ & [4] \\
\hline & $\begin{array}{l}\text { Moderate, larger black stains, occurring in up to } 50 \% \text { of shrimp } \\
\text { samples }\end{array}$ & [6] \\
\hline & Heavy, larger black stains, occurring in over $50 \%$ of shrimp samples & {$[8]$} \\
\hline & $\begin{array}{l}\text { Heavy blackening of the shrimp as a whole, occurring in } 100 \% \text { of } \\
\text { shrimp samples }\end{array}$ & {$[10]$} \\
\hline \multirow[b]{2}{*}{ Texture } & Normal & {$[0]$} \\
\hline & Softened & [2] \\
\hline \multirow{3}{*}{ Shell } & Strongly adhered & {$[0]$} \\
\hline & Mildly adhered & [2] \\
\hline & Weakly adhered & [4] \\
\hline \multirow{3}{*}{ Head } & Strongly adhered & {$[0]$} \\
\hline & Mildly adhered & [2] \\
\hline & Weakly adhered & [4] \\
\hline \multirow{6}{*}{ Appearance } & Excellent & {$[0]$} \\
\hline & Great & {$[2]$} \\
\hline & Good & [ 4 ] \\
\hline & Bad & [ 6 ] \\
\hline & Awful & {$[8]$} \\
\hline & Unacceptable & [10] \\
\hline QI total & & $0-36$ \\
\hline
\end{tabular}

\subsubsection{Data analysis}

The data were subjected to analysis of variance (ANOVA), and to tests for comparison of average, i.e. Student's $t$-test and Tukey's test, at 5\% level of significance using the SISVAR program version 5.6. For the QIM, a linear regression analysis was performed to predict the 
shelf life of shrimp, considering the maximum acceptable QI in white shrimp (L. vannamei) as $60 \%$ of the total score, as used by Oliveira et al. (2008).

\section{Results}

In the quality index method (QIM), the control group had a higher score $(\mathrm{p}<0.05)$ on all storage days when compared to shrimp samples subjected to different plasma frequencies. Plasma was found to be efficient in maintaining shrimp quality, because the QIM scores were reduced with the increasing frequency (Figure 2). Among the attributes assessed by the QIM, melanose appearance contributed the most to the loss of quality in samples, mainly from the control group.

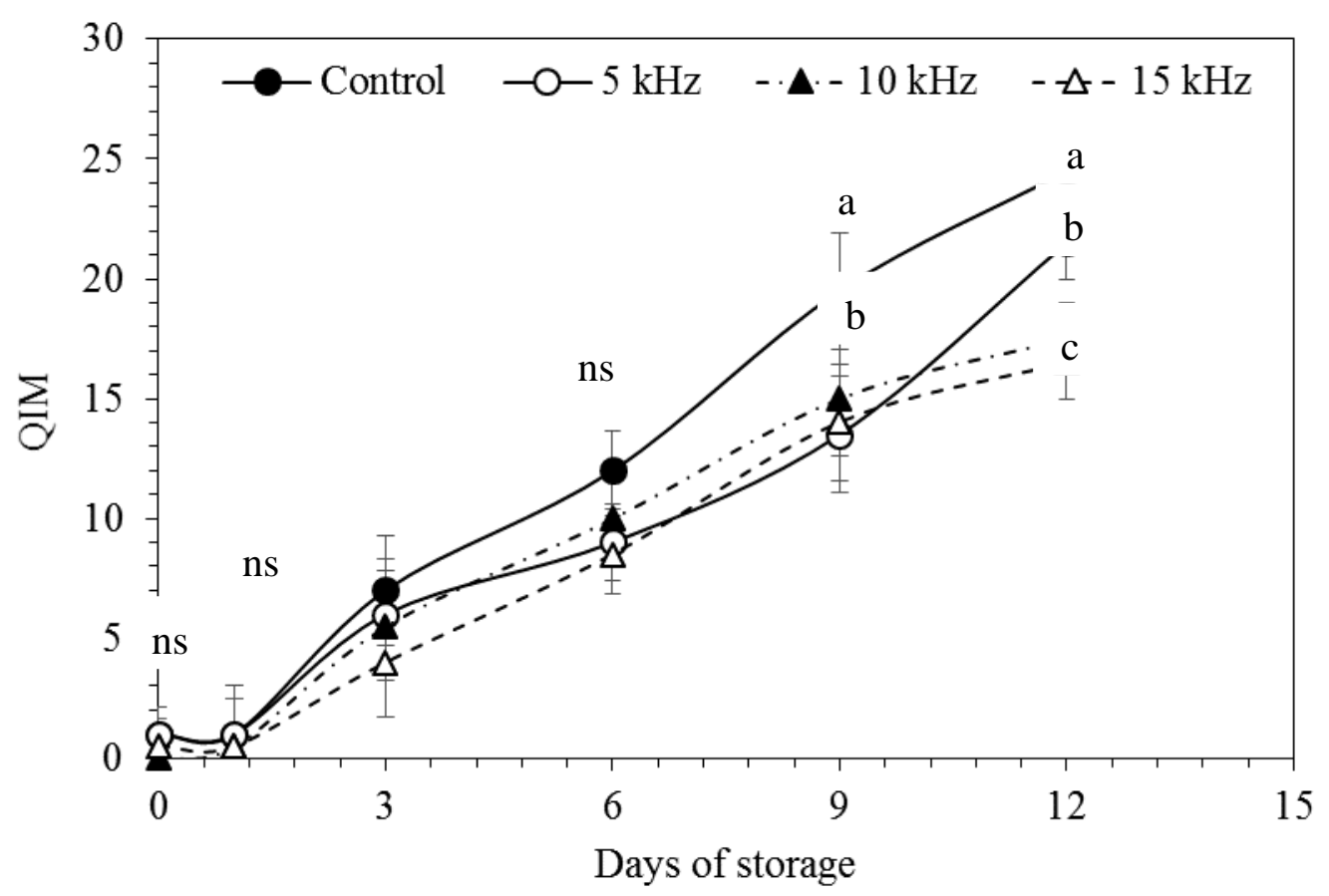

Figure 2. Quality indices of L. vannamei, subjected to cold plasma exposure at different frequencies, during 12 days of storage at $5 \pm 1^{\circ} \mathrm{C}$

Through linear regression analysis, it was possible to observe an increase in the shelf life of samples with an increase in plasma frequency (Table 2). The shrimp treated with cold plasma at a frequency of $15 \mathrm{kHz}$, presented approximately 16 days of shelf life, whereas the samples of the control group had a shelf life of 11 days.

Table 2. Shelf life of L. vannamei shrimp subjected to cold plasma treatment, as estimated by linear regression

\begin{tabular}{ccccc}
\hline & Linear regression model & $\mathbf{r}^{\mathbf{2}}$ & $\begin{array}{c}\text { Shelf life } \\
\text { (days) }\end{array}$ & p-value \\
\hline Control & $\mathrm{y}=2.0541 \mathrm{x}+0.2203$ & 0.9922 & 11.28 & $0.54 \mathrm{~ns}$ \\
$\mathbf{5} \mathbf{~ K H z}$ & $\mathrm{y}=1.6586 \mathrm{x}+0.097$ & 0.9747 & 13.52 & $0.15 \mathrm{~ns}$ \\
$\mathbf{1 0 ~ K H z}$ & $\mathrm{y}=1.5466 \mathrm{x}+0.0925$ & 0.9832 & 15.07 & 0.07 \\
$\mathbf{1 5 ~ K H z}$ & $\mathrm{y}=1.4451 \mathrm{x}-0.1331$ & 0.9877 & 16.28 & 0.01 \\
\hline
\end{tabular}

$\mathrm{y}=$ acceptable maximum QI (65\% of the total demerit points, i.e., 23.4); $\mathrm{x}=$ refrigerated days; $\mathrm{r}^{2}=$ regression coefficient. 


\section{Macrothink Institute ${ }^{T M}$}

Microbiological analyses of mesophilic bacteria indicated a reduction in the contamination in exposed samples of shrimp treated with plasma at $15 \mathrm{KHz}$, which differed statistically from the other samples, where the count increased with the storage period reaching approximately $4 \log \mathrm{CFU} \mathrm{g}{ }^{-1}$ at the end of the experiment (Figure 3).

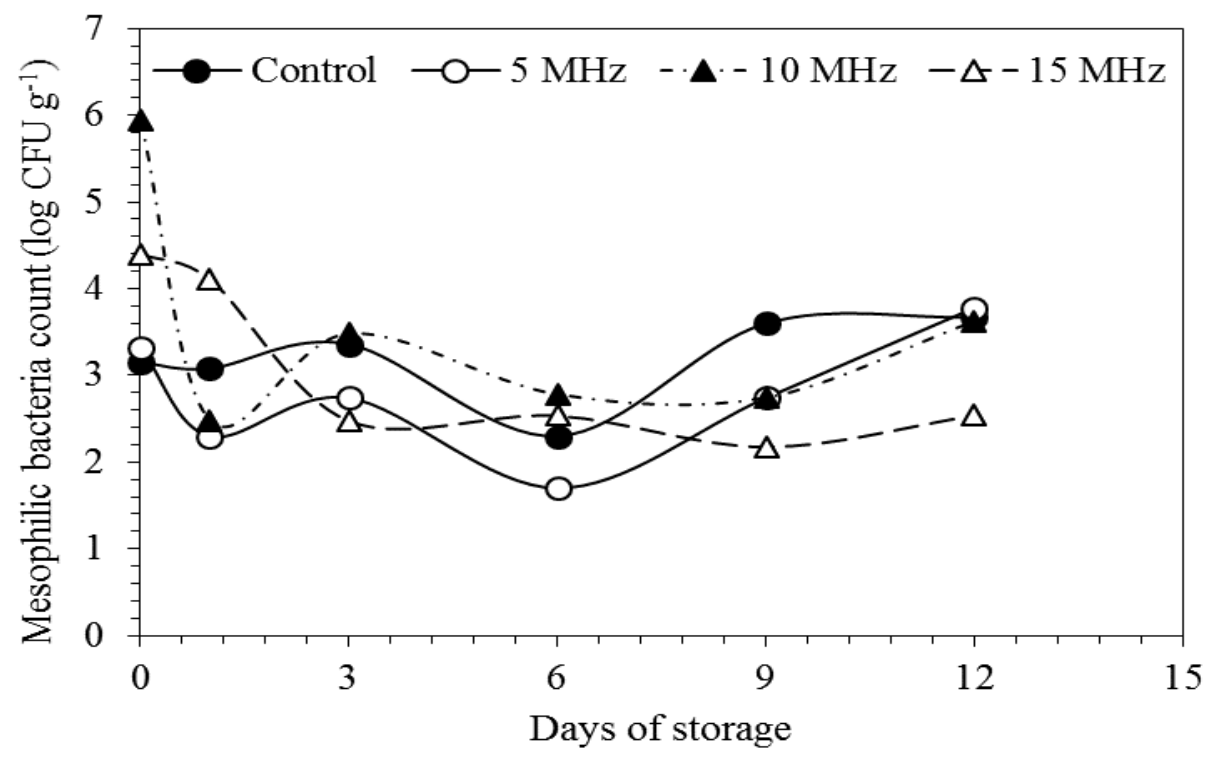

Figure 3. Total counts of mesophilic bacteria as a function of the storage period of Litopenaeus vanname $i$ with or without exposure to cold plasma

Regarding the psychotrophic bacterial counts, use of cold plasma with a power of $15 \mathrm{KHz}$ showed a significant bacteriostatic effect $(p<0.05)$ compared to the other treatments and the control group, with only a few colony forming units throughout the storage period ( $0.6 \mathrm{log}$ CFU g -1). On the other hand, the remaining groups showed a growth trend during storage, reaching $5 \log \mathrm{CFU} g-1$ on the last day of storage in the control group (Figure 4).

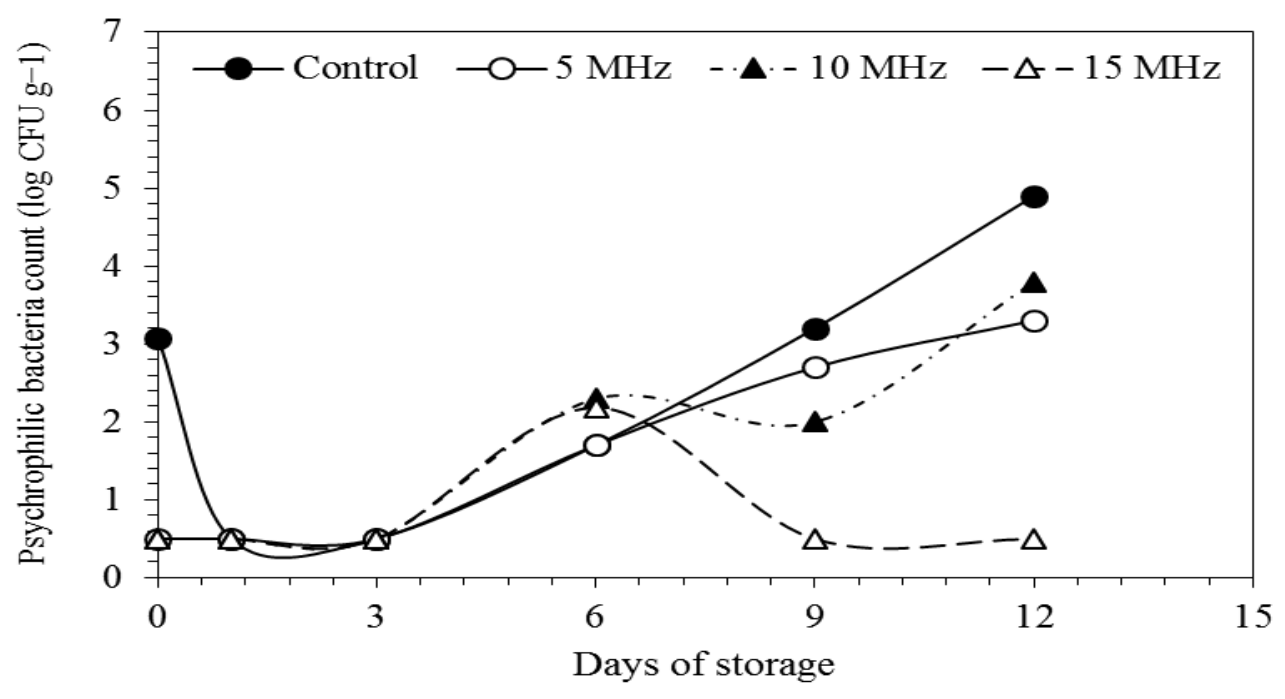

Figure 4. Total counts of psychrotrophic bacteria as a function of the storage time of $L$. vannamei, with or without exposure to cold plasma 


\section{Al Macrothink Institute ${ }^{\text {TM }}$}

Salmonella sp. showed negative results (absence), as recommended by the Regulation and Industrial and Sanitary Inspection of Products of Animal Origin (Brasil, 2017).

The total volatile bases (TVB) were increased during the storage period as all samples were within the limits permitted by current legislation (Brasil, 2017). The control group presented higher values ( $\mathrm{p}<0.05$ ) than the other treatments, reaching $24.76 \mathrm{mg} \mathrm{N} 100 \mathrm{~g}^{-1}$ at the end of the experiment, similar to values reported by Gonçalves et al. (2015). The cold plasma treatment had a direct effect on the production of total volatile bases in shrimp samples, with higher frequencies of plasma yielding lower values of TVB. Samples exposed to a frequency of $15 \mathrm{MHz}$ presented the lowest values, reaching a maximum value of $12.33 \mathrm{mg} \mathrm{N} 100 \mathrm{~g}^{-1}$ (Figure 5), equivalent to $50 \%$ of the TVB value in control samples.

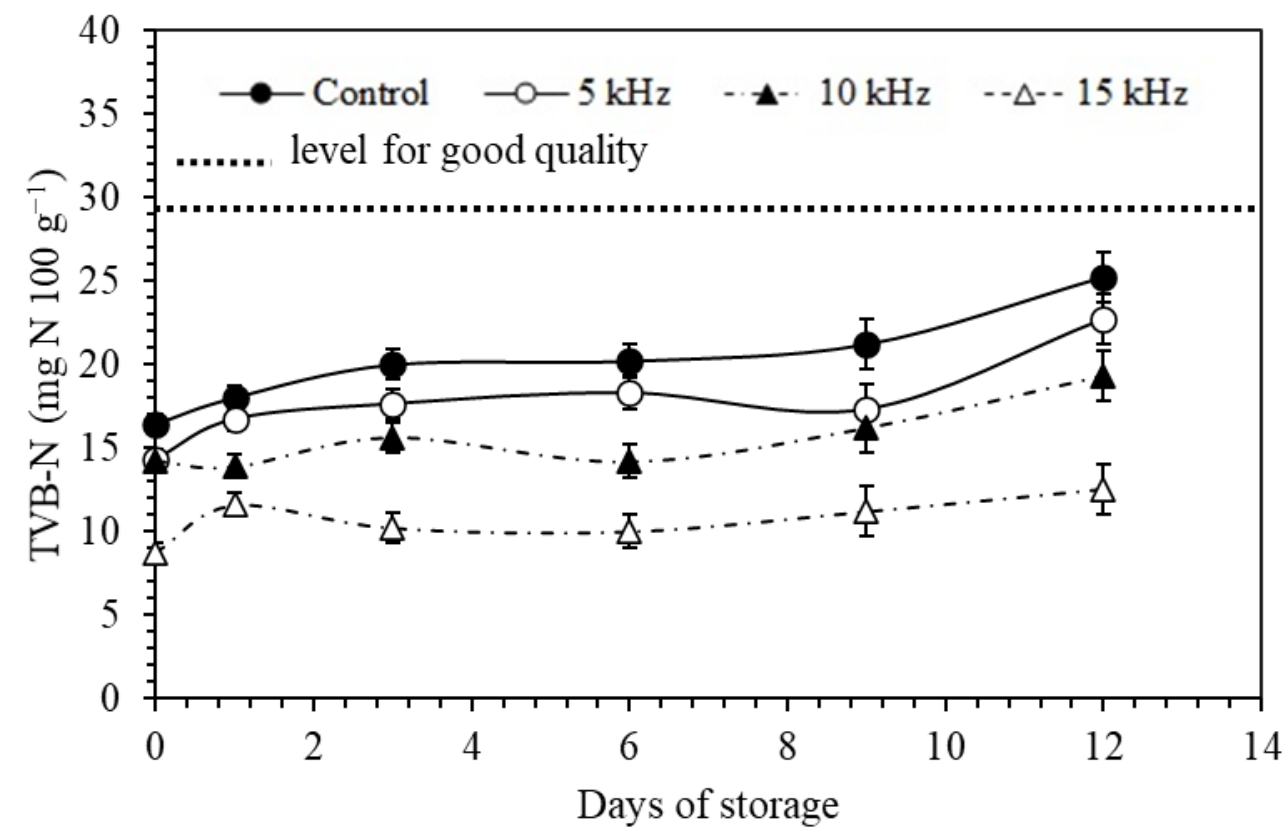

Figure 5. Effect of cold plasma on Nitrogen of Total Volatile Bases (N-TVB) in L. vannamei shrimp

In relation to trimethylamine (TMA), there was no statistical difference ( $p>0.05)$ between the samples, with values varying from 2 to $4 \mathrm{mg} \mathrm{N} 100 \mathrm{~g}$-1, which is the maximum limit allowed by legislation (Brasil, 2017), as can be seen in Figure 6. Trimethylamine (TMA) is mainly responsible for the changes in TVB values during the storage of sea fish in ice (Mendes \& Lajolo, 1975). 


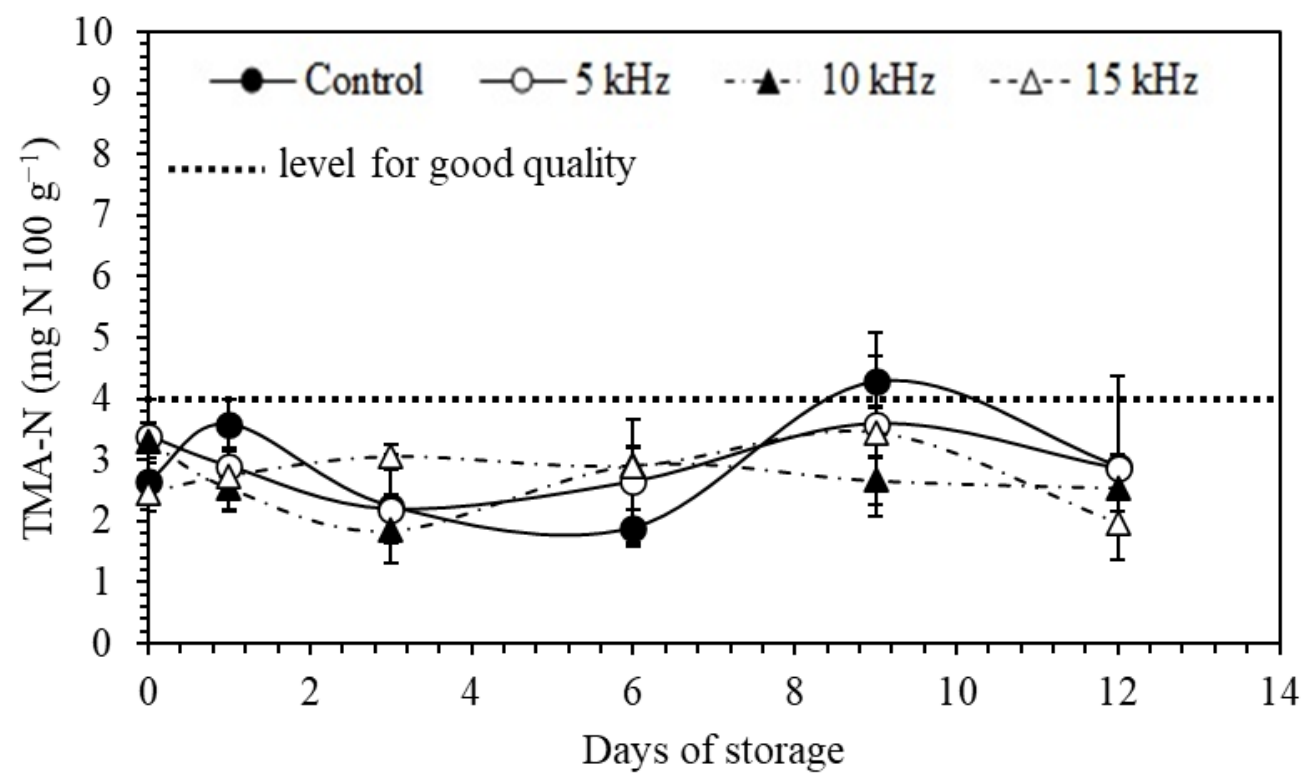

Figure 6. Effect of cold plasma on Tri-methylamine Nitrogen (N-TMA) in L. vannamei shrimp

The $\mathrm{pH}$ of the samples was stable until day 3 of storage, when all samples had $\mathrm{pH}$ between 6.1 and 6.4. From day 6 , there was an increase in the control group $\mathrm{pH}$, being significantly higher than that in the samples exposed to plasma, reaching $\mathrm{pH} 7.8$ at the end of the experiment. However, samples subjected to plasma treatment maintained a stable $\mathrm{pH}$, remaining within the legislation limit (Brasil, 2017) until the end of the experiment (Figure 7).

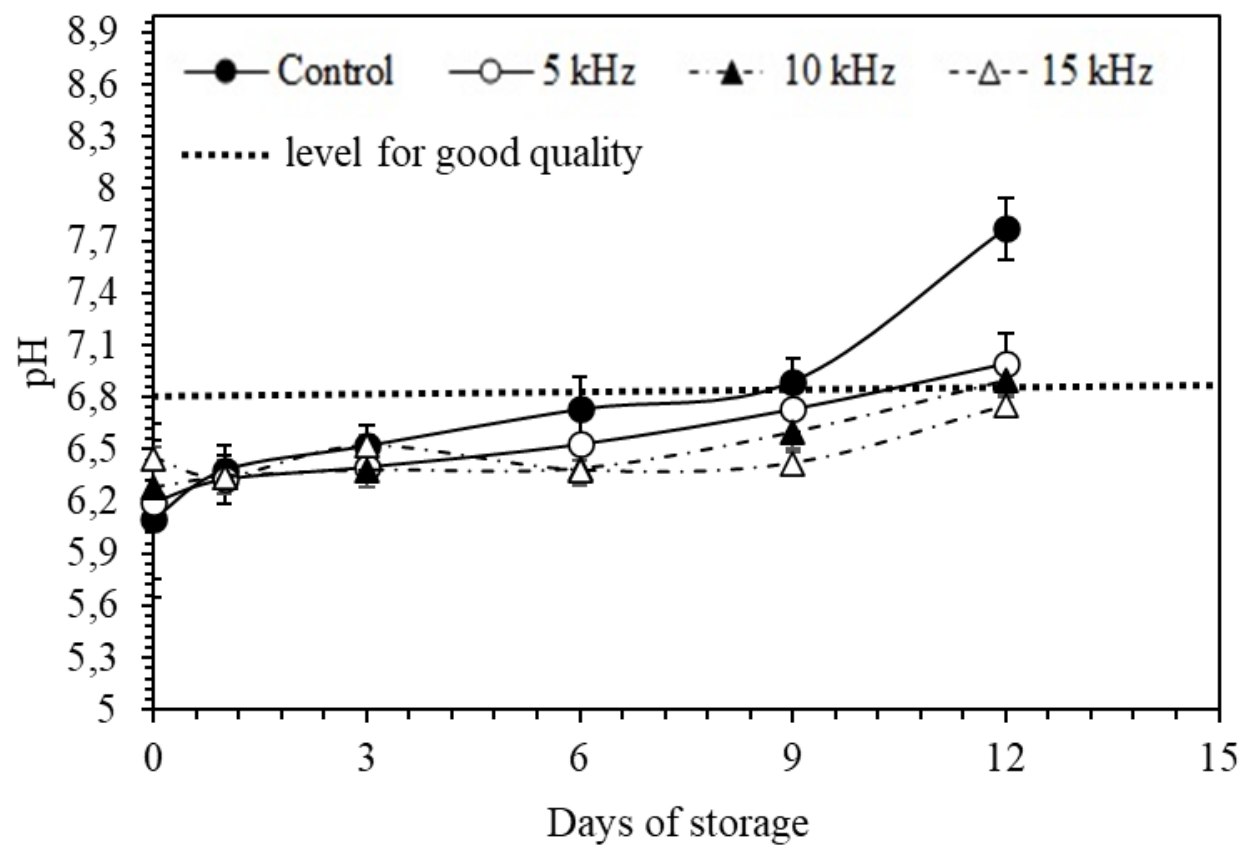

Figure 7. Effect of cold plasma on the $\mathrm{pH}$ of L. vannamei shrimp

Regarding color, a gradual increase in $\Delta \mathrm{e}$ values was observed with the increase in storage time. Plasma treatment was effective in the maintenance of the shrimp color, and the power 


\section{Al Macrothink

of $15 \mathrm{MHz}$ was the most efficient among the treatments, with the control group showing the highest color variation during storage (Figure 8).

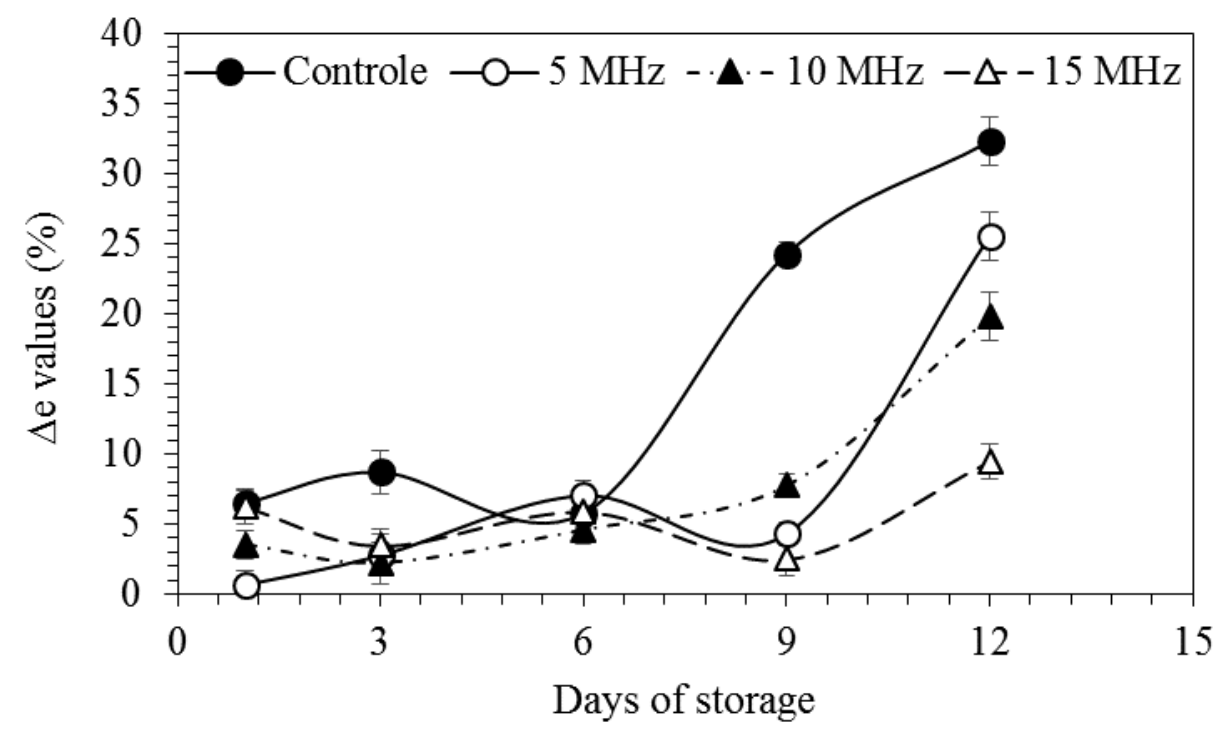

Figure 8. Effect of cold plasma on $\Delta \mathrm{e}$ and color variation in L. vannamei shrimp Analysis of thiobarbituric acid reactive substances (TBARS) showed no significant differences between the treatments. The product could be considered in good condition, presenting values below $3.0 \mathrm{mg}$ of malonaldehyde $/ \mathrm{kg}$ of sample, with lipid oxidation limits for consumption at 7-8 $\mathrm{mg}$ of MA/kg in food (Cadun, Kisla \& Cakli, 2008). The values for all groups did not reach $0.5 \mathrm{MA} / \mathrm{kg}$, and remained within the limit recommended by legislation.

Plasma treatment contributed significantly $(\mathrm{p}<0.05)$ to the increase in water retention capacity in the samples, showing a proportional relation with the sample capacity to retain liquid, reaching a water holding capacity of $80.4 \%$ at the beginning of the experiment samples subjected to plasma treatment at a frequency of $15 \mathrm{MHz}$, whereas the control group had a water holding capacity of $67.1 \%$ (Table 3).

According to Freire et al. (2016), several characteristics of the product are altered through the cooking process, including the fat and moisture contents. This consequently interferes with the weight/volume of the food, which is an important characteristic for the last group. The lowest weight loss occurred in plasma treated samples, and the group treated with the $15 \mathrm{MHz}$ frequency was the most satisfactory, since it was more efficient compared to the other groups, showing an inversely proportional relation with water holding capacity.

Regarding shear force, there was no difference between the samples treated with plasma and the control group, and the values ranged from 0.6 to $1.2 \mathrm{kgf} / \mathrm{cm}^{2}$. The shear force of the samples decreased with the storage period, reaching the lowest values at the end of the experiment. 
Table 3. Physicochemical characterization as a function of storage time in Litopenaeus vannamei, exposed to cold plasma

\begin{tabular}{|c|c|c|c|c|c|c|}
\hline \multirow{2}{*}{$\begin{array}{l}\text { Days of } \\
\text { storage }\end{array}$} & \multirow{2}{*}{ Physicochemical analysis } & \multirow[b]{2}{*}{ Control } & \multicolumn{3}{|c|}{ Plasma Frequencies } & \multirow{2}{*}{$\mathrm{CV}(\%)$} \\
\hline & & & $5 \mathrm{MHz}$ & $10 \mathrm{MHz}$ & $15 \mathrm{MHz}$ & \\
\hline 0 & \multirow{6}{*}{ TBArs (mg MDA / kg) } & $0.30 \mathrm{Ab}$ & $0.29 \mathrm{Aab}$ & $0.31 \mathrm{Aba}$ & $0.29 \mathrm{Ab}$ & \multirow{6}{*}{0.96} \\
\hline 1 & & $0.27 \mathrm{Ab}$ & $0.29 \mathrm{Aab}$ & $0.28 \mathrm{Ab}$ & $0.27 \mathrm{Ab}$ & \\
\hline 3 & & $0.31 \mathrm{Ab}$ & $0.29 \mathrm{Aab}$ & $0.29 \mathrm{Aab}$ & $0.31 \mathrm{Ab}$ & \\
\hline 6 & & $0.33 \mathrm{Aab}$ & $0.28 \mathrm{Ab}$ & $0.31 \mathrm{Aab}$ & $0.34 \mathrm{Aab}$ & \\
\hline 9 & & $0.34 \mathrm{Aab}$ & $0.36 \mathrm{Aa}$ & $0.34 \mathrm{Aab}$ & $0.32 \mathrm{Aab}$ & \\
\hline 12 & & $0.41 \mathrm{Aa}$ & $0.36 \mathrm{Aa}$ & $0.36 \mathrm{Aa}$ & $0.39 \mathrm{Aa}$ & \\
\hline 0 & \multirow{6}{*}{ Cooking loss (\%) } & $45.5 \mathrm{Ab}$ & 42.8 Abc & $39.5 \mathrm{BCd}$ & $37.1 \mathrm{Cb}$ & \multirow{6}{*}{3.02} \\
\hline 1 & & 46.6 Abc & $44.3 \mathrm{Abc}$ & $40.4 \mathrm{Bcd}$ & $39.2 \mathrm{Bab}$ & \\
\hline 3 & & 46.8 Abc & 43.5 Abbc & 42.2 Bcd & $40.3 \mathrm{Bab}$ & \\
\hline 6 & & 47.0 Abc & 44.7 Abbc & 41.7 Babc & $41.2 \mathrm{Ca}$ & \\
\hline 9 & & $49.7 \mathrm{Ab}$ & 46.7 Abab & 44.2 Bab & $41.8 \mathrm{Ca}$ & \\
\hline 12 & & 54.1 Aa & $48.9 \mathrm{Ba}$ & $46.3 \mathrm{Ba}$ & $42.8 \mathrm{Ca}$ & \\
\hline 0 & \multirow{6}{*}{ Shear force $\left(\mathrm{kgf} / \mathrm{cm}^{2}\right)$} & 1.2 Aa & $1.2 \mathrm{Aa}$ & $1.2 \mathrm{Aab}$ & 1.2 Aab & \multirow{6}{*}{12.18} \\
\hline 1 & & 1.2 Aab & 1.0 Aab & $1.3 \mathrm{Ab}$ & $1.3 \mathrm{Aa}$ & \\
\hline 3 & & $0.8 \mathrm{Abc}$ & 1.0 Aab & $1.0 \mathrm{Ac}$ & $0.9 \mathrm{Aabc}$ & \\
\hline 6 & & $0.9 \mathrm{Abc}$ & 0.9 Aabc & $0.9 \mathrm{Abc}$ & $0.9 \mathrm{Abcd}$ & \\
\hline 9 & & $1.0 \mathrm{Ac}$ & $0.7 \mathrm{Abc}$ & $0.9 \mathrm{Bbc}$ & 1.0 Acd & \\
\hline 12 & & $0.8 \mathrm{Ac}$ & $0.9 \mathrm{Ac}$ & $0.8 \mathrm{Ac}$ & $0.6 \mathrm{Ac}$ & \\
\hline
\end{tabular}

A,B Different upper case letters in the line indicate difference between treatments by Tukey's test $5 \%$.

a, b, c Distinct lowercase letters in column indicate difference between storage times by Tukey's test $5 \%$.

According to Freire et al. (2016), several characteristics of the product are altered through the cooking process, including the fat and moisture contents. This consequently interferes with the weight/volume of the food, which is an important characteristic for the last group. The lowest weight loss occurred in plasma treated samples, and the group treated with the 15 $\mathrm{MHz}$ frequency was the most satisfactory, since it was more efficient compared to the other groups, showing an inversely proportional relation with water holding capacity.

Regarding shear force, there was no difference between the samples treated with plasma and the control group, and the values ranged from 0.6 to $1.2 \mathrm{kgf} / \mathrm{cm}^{2}$. The shear force of the samples decreased with the storage period, reaching the lowest values at the end of the experiment. 


\section{Discussion}

Melanose, or "black spot", is a common problem in crustaceans during storage, occurring due to biochemical reactions catalyzed by the enzyme polyphenoloxidase (PPO) in the presence of oxygen to form dark pigments called melanin, concentrated mainly on the cephalothorax of the animal (Gonçalves \& Oliveira, 2016). According to Nirmal \& Benjakul (2009), shrimp generally have a limited shelf-life due to melanose formation, even though it is harmless to consumers, causing a drastic reduction in the acceptance and commercial value of the product.

The efficiency of plasma in reducing the melanization process can be explained by its potential in reducing the enzymatic activity of polyphenoloxidase (PPO). According to Surowsky et al. (2013), the active components generated in the formation of plasma including UV rays and reactive oxygen species such as atomic oxygen and hydroxyls $(\mathrm{OH})$, attack the cell membrane leading to lipid unsaturation, peroxide disintegration, and protein structure modification by the oxidation of some sensitive aromatic amino acids found in PPO that are essential for its activity, thus delaying the melanization process.

Plasma generated through the dielectric barrier discharge system (DBD) with the use of atmospheric air as a working gas generates UV rays, some reactive oxygen species $\left(\mathrm{O}^{2}\right)$ such as ozone $\left(\mathrm{O}^{3}\right)$, atomic oxygen, and depending on the humidity of the air, $\mathrm{OH}$ radicals (Guo, Huang \& Wang, 2015). According to Scholtz et al. (2015), such plasma-generated compounds have a bactericidal capacity, acting directly on the cell, as with UV rays where the incidence of the same on nucleic acids causes formation of thymine dimers that inhibit bacterial replication capacity. In addition to UV rays, plasma-generated ozone is also reported to reduce the microbial load in shrimp (Okpala et al., 2015).

Some studies such as that by Noriega et al. (2011), have already reported the efficiency of cold plasma as an efficient antimicrobial agent, specifically, in reducing the psychotrophic bacteria Listeria innocua on the surface of chicken breasts, presenting a reduction of $3.3 \mathrm{log}$ $\mathrm{CFU} \mathrm{g}{ }^{-1}$.

The effects of cold plasma as an antimicrobial agent in shrimp have not been reported, but some work has been conducted with the application of non-thermal plasma to fish. According to Lee et al. (2011), use of plasma with a mixture of helium and oxygen, showed a reduction in L. monocytogenes growth in smoked salmon. Park \& Ha (2015) reported that the counts of Cladosporium sp. and Penicillium citrinum in dried fish fillets was decreased in the presence of cold atmospheric plasma.

In the process of bacterial catabolism, volatile compounds are produced as a result of the degradation of fish nutrients such as amino acids and trimethylamine oxide (OTMA), which are degraded to indicators of microbial deterioration like total volatile bases (TVB), which include ammonia and trimethylamine among others (Giannini, 2003). Therefore, the total volatile bases, and specifically trimethylamine, are directly proportional to the level of contamination in the samples, which could be observed in the present study.

According to López-Caballero et al. (2007), crustaceans have high levels of non-protein nitrogen, facilitating bacterial activity or some endogenous enzymes, which result in elevation of $\mathrm{pH}$ during storage, through the presence of nitrogen compounds mentioned 
above, which are released in the presence of microorganisms.

According to $\mathrm{Hsu}$ (2017) one of the main quality parameters for determining shrimp freshness is color, and the main factor responsible for color variation $(\Delta \mathrm{e})$ in crustaceans during storage is the development of melanose, a process resulting from the action of polyphenoloxidase in the presence of oxygen. In the present study, the occurrence of melanization was higher in the control group, explaining the higher values of $\Delta \mathrm{e}$. The use of cold atmospheric plasma was efficient in delaying the melanization process, consequently resulting in lower color variations $(\Delta \mathrm{e})$ in shrimp during storage.

For Wachirasiri et al. (2016), water holding capacity is directly associated with the $\mathrm{pH}$ of meat; in samples with low $\mathrm{pH}$, acidity causes rapid denaturation of proteins, consequently decreasing the meat's ability to retain liquid. According to Carneiro et al. (2013), with increasing $\mathrm{pH}$ in the muscle, proteins move away from their isoelectric point, resulting in an increase in the net negative charge and consequently, an increase in the electrostatic repulsion between them. This repulsion favors retention of water in the product.

According to Moreno et al. (2008), water holding capacity influences the appearance of the sample before and during cooking, determining the juiciness at the moment of consumption. In addition to determining the meat's ability to retain water after the application of external forces (Muchenje et al., 2009), a low water holding capacity also promotes loss of nutritive value and results in the production of a dry sample with compromised softness (Moreno et al., 2008), because protein denaturation occurs in this process (Goñi, \& Salvadori, 2010).

\section{Conclusions}

Exposure of white shrimp (Litopenaeus vannamei) to cold plasma at a frequency of $15 \mathrm{KHz}$ and a contact time of 10 minutes promoted better physical, chemical, microbiological, and sensorial qualities of the shrimp, prolonging their storage time by 5 days. It may thus be suggested as an effective treatment for shrimp quality maintenance.

\section{References}

Barbetta, P. V. C., \& Grigio, R. (2014). Influência do tempo e do tipo de papel na metodologia de capacidade de retenção de água (CRA) por compressão de Hamm. Dissertação (M. Sc.). Universidade Tecnológica Federal do Paraná.

Basseto, A. L. C., Gonçalves, M. A. A., Barros, M. V., Vieira, F. D., \& Stradioto, J.P. (2017). Contribuições de tecnologias limpas para a indústria de laticínios. VII Congresso Brasileiro de Engenharia de Produção. Ponta Grossa, PR.

BRASIL. (1981). Ministério da Agricultura. Secretaria Nacional de Defesa Agropecuária. Laboratório Nacional de Referência Animal. Métodos analíticos oficiais para controle de produtos de origem animal e seus ingredientes: II - Métodos físicos e químicos. Brasília, 11: $5-6$.

BRASIL. (2003). Ministério da Agricultura, Pecuária e Abastecimento. Instrução Normativa $\mathrm{N}^{\circ}$ 62, de 26 de agosto de 2003. Oficializa os Métodos Analíticos Oficiais para Análises Microbiológicas para Controle de Produtos de Origem Animal e Água. Diário Oficial da União, Brasília.75.

BRASIL. (2017). Ministério da Agricultura, Pecuária e Abastecimento (MAPA). Decreto nº 
9.013, de 29 de março de 2017, aprova o novo Regulamento de Inspeção Industrial e Sanitária de Produtos de Origem Animal - RIISPOA. Brasília, DF: Diário Oficial da União, 1, 3-27.

Cadun, A., Kişla, D., \& Çakli, Ş. (2008). Marination of deep-water pink shrimp with rosemary extract and the determination of its shelf-life. Food Chemistry, 109, 81-87. https://doi.org/10.1016/j.foodchem.2007.12.021

Carneiro, C. S., Mársico, E. T., Ribeiro, R. O. R., Júnior, C. A. C., Álvares, T. S., \& Jesus, E. F. O. (2013). Studies of the effect of sodium tripolyphosphate on frozen shrimp byphysicochemical analytical methods and Low Field Nuclear Magnetic Resonance (LF 1H NMR). LWT - Food Science and Technology, 50, 40-14. https://doi.org/10.1016/j.lwt.2012.09.009

Freire, B. C. F., Soares, K. M. P., Costa, A. C. A. A., Souza, A. S., Silva, L. K. C., Góis, V. A., Bezerra, A. C. D. S., \& Gomes, H.A.N. (2016). Qualidade de camarão (Litopenaeus vannamei) minimamente processado. Acta Veterinaria Brasilica, 10, 150-155. https://doi.org/10.21708/avb.2016.10.2.5543

Giannini, D. H. (2003). Determinación de nitrógeno básico volátil (NBV) en pescado. Consideraciones generales. Alimentaria, 343, 49-54.

Gonçalves, A. A. (2015). Ozone as a safe and environmentally friendly tool for the seafood industry. Journal of Aquatic Food Product Technology, 25, 210-229. https://doi.org/10.1080/10498850.2013.841785

Gonçalves, A. A., \& Oliveira, A. R. M. (2016). Melanosis in crustaceans: A review. LWT Food Science and Technology, 65, 791-799. https://doi.org/10.1016/j.lwt.2015.09.011

Gonçalves, A. A., Oliveira, A. R. M., \& Abrantes, M. R. (2015). Acerola fruit as a possible antimelanotic agent in white Shrimp (Litopenaeus vannamei). Journal of Food Processing. https://doi.org/10.1155/2015/460617

Goñi, S. M., \& Salvadori, V. O. (2010). Prediction of cooking times and weight losses during meat roasting. Journal of Food Engineering, Essex, 100, 1-11. https://doi.org/10.1016/j.jfoodeng.2010.03.016

Guo, J., Huang, K., \& Wang, J. (2015). Bactericidal effect of various non-thermal plasma agents and the influence of experimental conditions in microbial inactivation: A review. Food Control, 50, 482-490. https://doi.org/10.1016/j.foodcont.2014.09.037

Hamm, R. (1961). Biochemistry of meat hydration. In: Advances in food research. Academic Press, 355-463. https://doi.org/10.1016/S0065-2628(08)60141-X

Hsu, F. L. K. (2017). Kinship and culture. Routledge. https://doi.org/10.4324/9780203787717

ISO - The International Organization for Standardization. (1993). Sensory analysis - general guidance for the selection, training, and monitoring of assessors. Part I: Selected assessors. Part II: Experts. Geneva: The Intl. Organization for Standardization Standard Nr 8586-1.

Lee, H. J., Jung, H., Choe, W., Ham, J. S., Lee, J. H., \& Jo, C. (2011). Inactivation of Listeria monocytogenes on agar and processed meat surfaces by atmospheric pressure plasma jets. 
Food Microbiology, 28, 1468-1471. https://doi.org/10.1016/j.fm.2011.08.002

López-Caballero, M. E., Martínez-Alvarez, O., Gómez-Guillén, M. D. C., \& Montero, P. (2007). Quality of thawed deepwater pink shrimp (Parapenaeus longirostris) treated with melanosis-inhibiting formulations during chilled storage. International Journal of Food Science and Technology, 42, 1029-1038. https://doi.org/10.1111/j.1365-2621.2006.01328.x

Martinsdóttir, E., Luten, J. B., Schelvis-Smit, A. A. M., \& Hyldig, G. (2003). Developments of QIM-past and future. Quality of fish from catch to consumer. Netherlands: Wageningen Academic Publishers, 265-272.

Mendes, M. H. M., \& Lajolo, F. M. (1975). Evolução das bases voláteis totais e da trimetilamina em pescados e o seu uso como indicador da qualidade. Revista de Farmácia e Bioquímica da Universidade de São Paulo, São Paulo, 13, 303-322.

Misra, N. N., Tiwari, B. K., Raghavarao, K. S. M. S., \& Cullen, P. J. (2011). Nonthermal plasma inactivation of food-borne pathogens. Food Engineering Reviews, 3, 159-170. https://doi.org/10.1007/s12393-011-9041-9

Moreno, G. M. B., Loureiro, C. M. B., \& Souza, H. B. A. (2008). Características qualitativas da carne ovina. Revista Nacional da Carne, São Paulo, 381, 76-90.

Muchenje, V., Dzama, K., Chimonyo, M., Strydom, P. E., Hugo, A., \& Raats, J. G. (2009). Some biochemical aspects pertaining to beef eating quality and consumer health: A review. Food chemistry, 112, 279-289. https://doi.org/10.1016/j.foodchem.2008.05.103

Nirmal, N. P., \& Benjakul, S. (2009). Melanosis and quality changes of Pacific White shrimp (Litopenaeus vannamei) treated with catechin during iced storage. Journal of Agricultural and Food Chemistry, Washington, 57, 3578-3586. https://doi.org/10.1021/jf900051e

Noriega, L. G., Feige, J. N., Canto, C., Yamamoto, H., Yu, J., Herman, M. A., .. Auwerx, J. (2011). CREB and ChREBP oppositely regulate SIRT1 expression in response to energy availability. EMBO reports, 12, 1069-1076. https://doi.org/10.1038/embor.2011.151

Okpala, C. O. R., Bono, G., Abdulkadir, A., \& Madumelu, C. U. (2015). Ozone (O3) process technology (OPT): an exploratory brief of minimal ozone discharge applied to shrimp product. Energy Procedia, 75, 2427-2435. https://doi.org/10.1016/j.egypro.2015.07.206

Oliveira, N. M. S., Oliveira, W. R. M., Nascimento, L. C., Silva, J. M. S. F., Vicente, E., Fiorini, J. E., \& Bressan, M. C. (2008). Avaliação físico-química de filés de tilápia (Oreochromis niloticus) submetidos à sanitização. Ciência e Tecnologia de Alimentos, 28, 83-89. https://doi.org/10.1590/S0101-20612008000100013

Park, S. Y., \& Ha, S. D. (2015). Application of cold oxygen plasma for the reduction of Cladosporium cladosporioides and Penicillium citrinumon the surface of dried filefish (Stephanolepis cirrhifer) fillets. International Journal of Food Science and Technology, 50, 966-973. https://doi.org/10.1111/ijfs.12730

Scholtz, V., Pazlarova, J., Souskova, H., Khun, J., \& Julak, J. (2015). Nonthermal plasma-a tool for decontamination and disinfection. Biotechnology advances, 33, 1108-1119. https://doi.org/10.1016/j.biotechadv.2015.01.002

Smeu, I., \& Ioananicolau, A. I. (2014). Enhancement of food safety - Antimicrobial effectiveness of cold plasma treatments. The Annals of the University Dunarea de Jos of 


\section{Macrothink}

Galati Fascicle VI - Food Technology, 38, 9-20.

Surowsky, B., Fischer, A., Schlueter, O., \& Knorr, D. (2013). Cold plasma effects on enzyme activity in a model food system. Innovative Food Science \& Emerging Technologies, 19, 146-152. https://doi.org/10.1016/j.ifset.2013.04.002

Tarladgis, B. G., Watts, B. M., \& Younathan, M. T. (1960). A distillation method for the quantitative determination of malonaldehyde in rancid foods. Journal of American Oil Chemist's Society, 37, 44-48. https://doi.org/10.1007/BF02630824

Tsironi, T., Dermesonlouoglou, E., Giannakourou, M., \& Taoukis, P. (2009). Shelf life modelling of frozen shrimp at variable temperature conditions. LWT - Food Science and Technology, 42, 664-671. https://doi.org/10.1016/j.lwt.2008.07.010

Wachirasiri, K., Wanlapa, S., Uttapap, D. D., \& Rungsardthong, V. (2016). Use of amino acids as a phosphate alternative and their effects on quality of frozen white shrimps (Penaeus vanamei). LWT-Food Science and Technology, 69, 303-311. https://doi.org/10.1016/j.lwt.2016.01.065

Warris, P. D. (2003). Ciência de la Carne. Acribia: Zaragoza, 309.

Yuan, G., Hua, L. V., Tang, W., Zhang, X., \& Sun, H. (2016). Effect of chitosan coating combined with pomegranate peel extract on the quality of Pacific white shrimp during iced storage. Food Control, 59, 818-823. https://doi.org/10.1016/j.foodcont.2015.07.011

\section{Copyright Disclaimer}

Copyright for this article is retained by the author(s), with first publication rights granted to the journal.

This is an open-access article distributed under the terms and conditions of the Creative Commons Attribution license (http://creativecommons.org/licenses/by/4.0/). 